\title{
Characteristics of fraud in the agro-industrial complex of Russia
}

\author{
Ekaterina Trunova ${ }^{1 *}$ \\ ${ }^{1}$ Institute of Service and Entrepreneurship (branch) of the Don State Technical University in Shakhty, \\ Shevchenko str., 147, Shakhty, 346500, Russia
}

\begin{abstract}
The article discusses measures of state support for the agricultural sector as one of the key areas of activity of the agro-industrial complex in the Russian Federation, analyzes common fraudulent schemes that act against the interests of state policy in the field of support and development of the fundamental directions of the agro-industrial complex. In addition, other types of fraud, common in this area of entrepreneurial and other economic activity, have been investigated. It is concluded that counteraction to such crimes has certain disadvantages. The paper proposes measures to improve the efficiency of disclosing and prosecuting crimes in the field of economic activity committed in the agricultural sector.
\end{abstract}

\section{Introduction}

Market relations in the Russian Federation are currently characterized by a number of negative features caused, first of all, by the destruction of economic ties that existed before, as well as by a low level of control over economic activity in the state. Not all the problems that arose during the change of the state political regime and type of economy were solved both at the legislative level and in practice. The high degree of humanization inherent in the state's policy in establishing and securing measures of criminal responsibility for committing crimes of an economic nature, including those directed against the normal activities and development of the country's agro-industrial complex, allows us to conclude that the level of registered crime in this area has decreased. However, as practice shows, these measures are not enough to talk about the normalization of economic relations and the elimination of criminal encroachments in the economy.

The sphere of the agro-industrial complex seems to be especially vulnerable in this regard. This conclusion is due to the high degree of importance of agriculture and agricultural production for the state economy of Russia, since the agro-industry is its basis, provides the country's population with jobs, forms food security, and supports the economic independence of the Russian Federation on the world stage. At the same time, it should be noted the role of supporting national agro-industrial activities in the context of global economic instability and the trend towards import substitution. An effective method of support is the provision of subsidies to farms, individual entrepreneurs and legal entities engaged in the production and sale of agricultural products. To continue growing, Russian agriculture must pay special

${ }^{*}$ Corresponding author: trun3007@mail.ru 
attention to the cultivation of unused land and the introduction of new technologies to increase the relatively low yields and livestock production [1].

Turning to existing research on the impact of agricultural crime, most of the existing academic research focuses almost exclusively on the financial impact of agricultural crime. However, there is research on how agricultural crime affects the health of farmers. It examines not only how agricultural crime affects the mental health and well-being of farmers in Britain, but also how agricultural crime compares with other drivers of agriculture in its impact on the mental health of British farmers [2].

The criminal legislation of the Russian Federation in the field of combating economic crime in the field of the agro-industrial complex is characterized by a number of contradictions that cause certain difficulties in qualifying socially dangerous acts aimed at the illegal use of budget funds allocated to support agricultural activities. As an example, we can imagine a situation in which funds appropriated through fraudulent actions in the field of lending or receiving payments that fall under the special rules of the Criminal Code of the Russian Federation cannot be considered a subject of a crime if these frauds are committed in the field of subsidizing the agro-industrial complex. The reason for this is the clearly formulated subject of such acts and the methods of their commission. The general rule on fraud (Article 159 of the Criminal Code of the Russian Federation), although it contains signs of encroachments committed in the course of business, however, it focuses on deliberate failure to fulfill contractual obligations. At the same time, crimes committed in the field of subsidizing the agro-industrial complex do not imply the deliberate use of objectively existing contractual relations, since there are none. In addition, the current legislation has not finally resolved the issue of the corruption component during competitive and other procedures during which candidates are selected for the provision of state support measures.

In connection with the above, crimes in the field of subsidizing the agro-industrial complex become highly latent. In addition, in the absence of their independent registration by the internal affairs bodies, the general structure of the registered encroachments of the group in question acquires incompleteness.

The purpose of the scientific article is to develop recommendations regarding measures to improve the efficiency of disclosing and prosecuting economic crimes committed in the field of the agro-industrial complex.

\section{Methodology}

Methods used in the study: methods of systematization and generalization, comparative method, methods of induction and deduction.

\section{Results of the research}

The analysis of state activities in the field of the agro-industrial complex, carried out within the framework of this study, allows us to conclude that there is a high degree of significance agriculture and agricultural production. This area forms the basis of the national economy and contributes to the formation of food security. This determines the need and importance of serious state support for the agro-industrial complex in Russia. However, a simple allocation of funds from the state will not be able to ensure the normal, let alone progressive development of agriculture without proper control over the funds provided and their intended use. To ensure proper control of the turnover of funds allocated for the development and support of the agricultural sector, the state should receive an accounting system. 
The specificity of financial and economic activities and the organization of economic ties in agriculture makes it difficult to identify and document fraud in the agro-industrial complex [3]. Meanwhile, there has been a continuous rise in economic crime in agriculture.

High-quality preparation for the study based on the selection of relevant information, the choice of an effective method for checking documents is the key to formulating the correct conclusions in the certificate. Checking the documentation of business transactions to identify fraudulent schemes in the agro-industrial complex can be carried out in the form of a formal check (checking a separate document) and a substantive check (checking related documents.). When choosing a method for verifying the documentation of an agricultural organization, audit specialists should rely on the degree of reliability and reliability of accounting information, which is ensured by compliance with the legal requirements.

Recommended research algorithm:

1. Information support of the conducted research:

a) establishing, on the basis of the requirements of regulatory legal documents, the procedure for receiving a particular payment and the conditions for its provision;

b) determination of the list of required accounting documentation (title documents, primary documents, accounting registers, financial statements (and primarily specialized), statistical reporting).

2. Preparation for documentary research:

a) determination of the sufficiency of documentation for the study;

b) establishing the need for information from third parties based on requests and confirmations;

c) determining the need for actual control measures (inventory, control measurements, control milking, control threshing, etc.).

3. Conducting documentary research:

a) formal (regulatory) examination of documents;

b) examination of documents on the merits to establish forensically significant facts and circumstances;

c) determination of the amount of damage and the circle of persons who issued and signed forged documents (if these circumstances are found).

4. Formulation of conclusions. The conclusions of a specialist auditor are assessed not only by the body or person who commissioned the study, from the standpoint of the level of their significance and reliability, but also by himself from the point of view of the reality of using the results.

\section{Discussion of results}

\subsection{Measures of state support for the agro-industrial complex in Russia}

Russian agriculture has never seen an easy time. But now, judging by the rise in food prices, the situation is somewhat worse than usual. As a result of risky socio-economic experiments, inconsistent government policy, the domestic agro-industrial complex was unable to ensure food security in Russia.

The activity of the agro-industrial complex includes 4 main areas: agriculture, which occupies a key place in the complex, which also consists of: crop production, animal husbandry, farms, personal subsidiary plots, etc.

The next sphere of the agro-industrial industry is represented by industries and services that provide agriculture with means of production and material resources, such as: tractor and agricultural engineering, the production of mineral fertilizers, chemicals, etc. 
Another area of activity of the agro-industrial complex is the industries that provide the processing of agricultural raw materials, they include the food industry and industries for the primary processing of raw materials for the light industry $[4,5]$.

The last in the activity of the complex under consideration can be identified the infrastructural block - that is, industries that are engaged in the procurement of agricultural raw materials, transportation, storage, trade in consumer goods, training for agriculture, construction in the sectors of the agro-industrial complex. That is, the infrastructure block is not directly related to the production of products, it only provides the possibility of its implementation and bringing it to the end consumer.

In this article, we will focus on the activities of such a block as agriculture, namely animal husbandry. The state, as mentioned above, is interested in the development of its own, independent of external factors, agricultural production, which could produce a sufficient amount of quality products for its citizens, as well as be competitive on the world stage, which would give additional income to the state treasury.

To accomplish this task, it is necessary to provide domestic manufacturers with modern technologies with maximum performance at a minimum cost. This proposal can be put into practice only with financial support, both with its own funds and funding from outside.

Such a field of human activity as animal husbandry requires high costs, in addition, they are associated with risks, upon the occurrence of which producers may completely cease to exist on the market, and this, in turn, may directly entail a decrease in the produced product and interruptions in the supply of food. , and many socio-economic problems, for example, unemployment, capital outflow, etc. [6]

The state, fully aware of the possibility of such a scenario, provides support to the subjects of agricultural production, both directly, by providing funds, and indirectly, by providing various benefits, including tax [7]. Also, various programs are being developed for the development of the agro-industrial complex both as a whole and its individual elements. Among the measures taken at the state level, contributing to the exit of Russian agriculture as a whole from the systemic crisis that has been going on since the Soviet period of development, it should be especially noted that the system of normative legal acts that is being formed, which includes state programs, concepts and doctrines, legislative and by-laws as state, and at the regional level. They, in turn,

The state program determined the goals, objectives and main directions of the development of agriculture and regulation of the agri-food market, financial support and mechanisms for the implementation of the planned activities and indicators of their effectiveness; provided for the comprehensive development of all industries and sub-sectors, as well as areas of activity of the agro-industrial complex, taking into account Russia's membership in the World Trade Organization, its participation in the Eurasian Economic Union and other regional associations in the economic space of the CIS [8].

However, it should be noted that a simple allocation of funds, no matter how large their size may be, will not be able to ensure the normal, and even more progressive, development of agriculture without proper control over the funds provided and their intended use, but this is not all. It is important that funding goes to really developing projects that provide an increase in agricultural production. That is, it is necessary to allocate funds not only to conscientious participants in agricultural production, but also to successful people who know their business. Contradictory and inconsistent state economic reforms have led to the strongest criminalization of the agro-industrial complex. Crimes in this area contribute to the outflow of funds from the legal economy to the "shadow" one,

Currently, in order to properly control the turnover of funds allocated for the development and support of the agricultural sector, an accounting system should come to help the state. The modern accounting system in Russia suffers from unscrupulous producers who 
fraudulently try to obtain funds for development, but having received them, they spend it on their own purposes not related to agriculture.

\subsection{Crimes of a fraudulent nature committed in the agro-industrial complex}

The state of the national agro-industrial complex determines not only economic, but also national security, in this regard, combating crime in the agricultural sector is becoming one of the priority tasks of the operational and investigative divisions of the internal affairs bodies. However, there is a strict dependence: as far as the patterns of criminal activity are fully identified, so can one count on the emergence of effective methods for identifying and solving certain types and groups of crimes.

The study of criminal cases and operational materials allows us to talk about the spread of fraudulent schemes of theft of funds allocated for the development of the agro-industrial complex. First of all, attention is drawn to the theft of funds allocated in the form of subsidies designed to stimulate the development of animal husbandry.

Another common method of committing a crime under Article 159.2 of the Criminal Code of the Russian Federation is the theft of funds allocated to provide affordable housing for young professionals (or their families) in the countryside. This is done by submitting forged documents to the department of architecture, construction and housing and communal services of the Administration of municipalities by citizens who have nothing to do with agriculture and do not live in rural areas stating that a certain person is a young specialist in an agro-industrial complex and needs housing.

A typical situation is when the fraud provided for in Article 159.2 of the Criminal Code of the Russian Federation is committed in combination with falsification of documents, namely, officials of the village administration prepare forged documents on the intended use of the loan received within the framework of the national project for the development of the agro-industrial complex, as a result of which they a subsidy is provided to repay part of the interest on the loan.

An analysis of this kind of criminal cases shows that in proving the most important and difficult moment is the establishment of a direct intent to steal already when drawing up documents for obtaining a subsidy (insurance, etc.) and the lack of desire to fulfill their obligations. An obligatory element of proof is the seizure and admission to the case of documents that acted as a means of committing a crime.

The materials obtained in the course of operational-search activities become, in the course of the investigation, materials of the actual criminal case and sources of criminal procedural evidence for the court. Unfortunately, in recent years, there has been a degradation of this very component of criminal prosecution: operational approaches to the objects of the agroindustrial complex and priority areas of operational services have been lost.

It seems to be a false setting that the state should distance itself as much as possible from participation in the economic activities of economic entities, and law enforcement agencies should stop exercising total control over business. The consequences of such a criminal policy in the field of combating economic crime are justly criticized.

In modern conditions, successful counteraction to economic crime, especially in its organized forms, requires a reform of the prosecutorial power and the legal mechanism of its activity. Otherwise, the imitation of the fight against economic crime will continue, rather than the real fight [9].

The Criminal Code of the Russian Federation defines fraud as "theft of someone else's property or the acquisition of the right to someone else's property by deception or abuse of trust." By means of stealing someone else's property or acquiring the right to someone else's property in case of fraud, responsibility for which comes in accordance with Art. 159, 159.1, 159.2, 159.3, 159.5 of the Criminal Code of the Russian Federation, are deception or abuse 
of trust, under the influence of which the owner of the property or another person transfers the property or the right to it to another person or does not prevent the seizure of this property or the acquisition of the right to it by another person.

In accordance with the definition, there are two characteristic ways of committing crimes of this type: deception or abuse of trust, as well as two types of fraud - theft of someone else's property and the acquisition of the right to someone else's property.

Deception as a way to steal property can be implemented in two forms. Active deception involves deliberate misleading of the owner of the property by means of knowingly reporting false information or taking actions aimed at misleading the owner of the property or another person and persuading to transfer property or the right to this property to other persons. Passive deception consists in keeping silent about the legally significant factual circumstances that the offender was obliged to disclose, as a result of which the person transferring the property is mistaken about the existence of legal grounds for transferring the property to the guilty person or the right to it. Abuse of trust in fraud is the use of a trust relationship with the owner of the property or another person for a mercenary purpose,

The methods of committing fraudulent actions in the field of the agro-industrial complex distinguish this type of criminal activity from other economic crimes in the field of the national economy. This is due, first of all, to the specifics of this field of activity, as well as the high level of its funding from the state and regional budgets [11].

Table 1. The state of economic crime in agriculture in Russia in 2014-2018.

\begin{tabular}{|l|c|c|c|c|c|c|}
\hline \multicolumn{1}{|c|}{ Index } & $\mathbf{2 0 1 4}$ & $\mathbf{2 0 1 5}$ & $\mathbf{2 0 1 6}$ & $\mathbf{2 0 1 7}$ & $\mathbf{2 0 1 8}$ & $\begin{array}{c}\mathbf{2 0 1 8} \text { to } \\
\mathbf{2 0 1 4} \%\end{array}$ \\
\hline Economic crimes, units: & 107797 & 112445 & 108754 & 105087 & 109463 & 101.55 \\
\hline - Total & 990 & 1137 & 1403 & 1486 & 1252 & 126.46 \\
\hline - in agriculture & \multicolumn{7}{|l|}{} & & \\
\hline Fraud, units: & 20967 & 22108 & 22397 & 24916 & 26002 & 124.01 \\
\hline - Total & 294 & 320 & 475 & 546 & 647 & 220.07 \\
\hline - in agriculture & 28.14 & 33.86 & 36.74 & 51.68 & - \\
\hline $\begin{array}{l}\text { The share of fraud } \\
\text { in the total } \\
\text { number of } \\
\text { economic crimes } \\
\text { in agriculture, } \%\end{array}$ & 29.70 & & & & \\
\hline
\end{tabular}

\subsection{Methods for detecting fraudulent schemes in the agro-industrial complex}

The most pressing problems faced by the employees of the relevant departments of the Ministry of Internal Affairs of Russia when examining documents in the field of the agroindustrial complex are:

1) the specificity of the activities of economic entities in the sphere of the agro-industrial complex;

2) the complication of mechanisms for committing fraudulent actions in the field of the agro-industrial complex in recent years;

3) the variety of fraudulent schemes used by the subjects of illegal activities in the agroindustrial complex;

4) the connection of fraudulent schemes with the specifics of agricultural activities, the lack of transparency in the financial and economic activities of enterprises in the agroindustrial complex;

5) the complexity of legal regulation of financial, economic and accounting activities of enterprises of the agro-industrial complex; 
6) failure to provide information upon request by the subjects of control and supervisory activities in the field of the agro-industrial complex, credit institutions, counterparties;

7) lack of uniform standards for reflecting information on the activities of agricultural and processing enterprises in the accounting and reporting system;

8) inadequacy (absence) of methodological recommendations on the identification and documentation of crimes related to fraudulent actions in the field of the agro-industrial complex;

9) the lack (absence) of methodological recommendations on the determination of the amount of material damage caused by illegal actions in the field of the agro-industrial complex [12].

The groups of problems identified by the audit specialists can be classified as follows:

- criminal law problems (due to the problems of identifying objects of primary interest, qualifying the composition of fraudulent actions, the need to comply with the established research deadlines);

- problems associated with the specifics of the economic activities of enterprises of the agro-industrial complex (high dependence on natural conditions, unverifiability of the real yield of agricultural crops and animals, establishing the quality of products solely on the basis of laboratory methods);

- methodological problems (due to the presence of regulatory and legal problems in the regulation of the activities of enterprises of the agro-industrial complex and the organization of accounting in them, formal control by the control and supervisory authorities, the inability to develop a single verification method due to the variety of used accounting documentation, techniques and forms of accounting) [13].

The ranked list of the research problems most relevant to audit specialists is as follows:

1) neglect of accounting at enterprises of the agro-industrial complex and its maintenance manually, without the use of automation tools;

2) formal control over activities on the part of control and supervisory bodies and, first of all, regional Departments (ministries) of agriculture of Russia;

3) a simplified and simple accounting procedure used in most agricultural organizations and, above all, in peasant (farm) farms;

4) ineffectiveness of traditional methods of document research.

Thus, it should be recognized that it is the specificity of financial and economic activities and the organization of economic ties in agriculture that makes it difficult to identify and document fraud in the agro-industrial complex. False information reported in fraud (or information that is not disclosed) can relate to any circumstances, in particular, to legal facts and events, quality, value of property, identity of the perpetrator, his powers, intentions, which determines the special role of a certificate on the study of documents as the most important source of evidence that allows you to correctly determine the objective side of the crime [14].

High-quality preparation for the study based on the selection of relevant information, the choice of an effective method for checking documents is the key to formulating the correct conclusions in the certificate. Checking the documentation of business transactions to identify fraudulent schemes in the agro-industrial complex can be carried out in the form of a formal check (checking a separate document) and a substantive check (checking interrelated documents.) [15]. When choosing a method for verifying the documentation of an agricultural organization, audit specialists should rely on the degree of reliability and reliability of accounting information, which is ensured by compliance with the legal requirements.

Recommended research algorithm:

1. Information support of the conducted research: 
a) establishing, on the basis of the requirements of regulatory legal documents, the procedure for receiving a particular payment and the conditions for its provision;

b) determination of the list of required accounting documentation (title documents, primary documents, accounting registers, financial statements (and primarily specialized), statistical reporting).

2. Preparation for documentary research:

a) determination of the sufficiency of documentation for the study;

b) establishing the need for information from third parties based on requests and confirmations;

c) determining the need for actual control measures (inventory, control measurements, control milking, control threshing, etc.).

3. Conducting documentary research:

a) formal (regulatory) examination of documents;

b) examination of documents on the merits to establish forensically significant facts and circumstances;

c) determination of the amount of damage and the circle of persons who issued and signed forged documents (if these circumstances are found).

4. Formulation of conclusions. The conclusions of a specialist auditor are assessed not only by the body or person who commissioned the study, from the standpoint of the level of their significance and reliability, but also by himself from the point of view of the reality of using the results.

Carrying out a study of documents related to fraudulent actions in the field of the agroindustrial complex before the initiation of a criminal case has its own characteristics. The most important of them is that falsification of accounting documents is carried out before the conclusion of the relevant contracts and (or) the emergence of obligations and confirms the presence of intent on the part of the subject of illegal activity, the intentionality of fraudulent actions. Therefore, the conclusions contained in such a certificate are extremely important for establishing the presence of corpus delicti by the law enforcement officer.

Thus, the role of document research in identifying and documenting fraudulent activities in the agricultural sector can hardly be overestimated. It is the accounting documents that make it possible to form a trace picture of fraudulent actions, assess the amount of damage and determine the circle of responsible persons [16]. At the same time, the study of accounting documents in the field of agricultural production is characterized by many problems, of which the most important are the specificity of departmental legislation in the field of accounting, the multiplicity of accounting documents related to the specifics of agricultural activities, the lack of transparency and unverifiability of a number of economic processes.

\section{Conclusions}

In modern conditions, successful counteraction to economic crime, especially in its organized forms, requires a reform of the prosecutorial power and the legal mechanism of its activity. Another important condition for the effectiveness of countering fraud in the agro-industrial complex is the development of a clear methodology for studying the accounting documents of the relevant agricultural processes. Otherwise, the imitation of the fight against economic crime will continue, rather than the real fight. 


\section{References}

1. V. Uzun, N. Shagaida, Z. Lerman, Land Use Policy 83, 475-487 (2019) doi.org/10.1016/j.landusepol.2019.02.018

2. K. Smith, Journal of Rural Studies 80, 522-531 (2020) doi.org/10.1016/j.jrurstud.2020.10.037

3. J. Théolier, V. Barrere, S. Charlebois, S. Benrejeb Godefroy, Journal of Banking \& Finance 107, 480-490 (2021) doi.org/10.1016/j.tifs.2020.11.017

4. F. Curti, A. Mihov, Journal of Banking \& Finance 87, 446-461 (2018) doi.org/10.1016/j.jbankfin.2017.11.009

5. D. Grace, Food Fraud, Encyclopedia of Food Security and Sustainability (Elsevier, 2019) doi.org/10.1016/B978-0-08-100596-5.21577-1

6. H. Montgomery, S.A. Haughey, Ch.T. Elliott, Global Food Security 26 (2020) doi.org/10.1016/j.gfs.2020.100447

7. Y. Yang, W. Huisman, K.A. Hettinga, N. Liu, J. Heck, G.H. Schrijver, L. Gaiardoni, S.M. van Ruth, Food Control 95, 308-317 (2019) doi.org/10.1016/j.foodcont.2018.08.019

8. E. Dante Gutierrez, International Journal of Drug Policy (2021) doi.org/10.1016/j.drugpo.2020.103091

9. L. Manning, R. Smith, J. Mei Soon, Food Policy 59, 44-54 (2016) doi.org/10.1016/j.foodpol.2015.12.003

10. L. Guilherme Scorzafave, M. Justus, P. Francisco Assis Shikida, Journal of Rural Studies 39, 247-261 (2015) doi.org/10.1016/j.jrurstud.2014.12.002

11. J. Janker, S. Mann, S. Rist, Journal of Rural Studies 65, 32-42 (2019) doi.org/10.1016/j.jrurstud.2018.12.010

12. G. Enticott, Journal of Rural Studies 27-2, 200-208 (2011) doi.org/10.1016/j.jrurstud.2011.01.005

13. V. Vladimirova, Journal of Rural Studies 53, 247-258 (2017) doi.org/10.1016/j.jrurstud.2017.02.004

14. F. Jawadi, S.K. Mallick, A. Idi Cheffou, A. Augustine, Journal of Economic Behavior \& Organization (2019) doi.org/10.1016/j.jebo.2019.03.025

15. B. Hyseni, Procedia - Social and Behavioral Sciences 149, 409-416 (2014) doi.org/10.1016/j.sbspro.2014.08.199

16. Y. Griewald, Ecological Economics 151, $1-9 \quad$ (2018) doi.org/10.1016/j.ecolecon.2018.04.026 